\title{
CLIMATE RISKS ASSESSMENT, OPPORTUNITIES RELATED TO THE EVOLUTION OF ECOSYSTEMS AND LIMITATION OF THE PROVISION OF ECOSYSTEM SERVICES: LANDSCAPE CASE OF SOUTH-KIVU (ALBERTINE RIFLT, DRC)
}

Aruna Sefu 1,2, Kimenya Musailwa 1,3, Bitundu Mwanya Tanya 4, M’opandu Mondonge 5, Lwimo Mukenge 6, Kambale Kavusa Gentil 7, Mangambu Mokoso Jean De Dieu ${ }^{*} \otimes$

${ }^{1}$ Institut Supérieur de Développement Rural, Département de l’Environnement \& Développement Durable, ISDR-KINDU, RD Congo.

2 Executive Director of Congo Basin Conservation Society CBCS-Network

${ }^{3}$ Université de Kisangani, Faculté de Psychologie \& des Sciences de l’Education, Département des Sciences de l'Education, Kisangani, RD Congo.

${ }^{4}$ Institut Supérieur de Développement Rural, Département de l'Environnement \& Développement Durable, ISDR-Bukavu, RD Congo.

${ }^{5}$ Institut Supérieur d'Etudes Agronomiques, Département d'Agronomie Générale, ISEA-Basoko, RD Congo.

6 Université Libre des Pays des Grands Lacs - Bukavu, Faculté de Santé et Développement, Département de Santé et Environnement, Bukavu, RD Congo.

7 World Wildlife Fund (Bukavu -DRC) \& UNICAF University, Département d'Administration des Affaires et Management, Chypres du Nord/l'Union Européenne.

8 Université officielle de Bukavu, Faculté des sciences, Département de Biologie, Laboratoire de Systématique, Biodiversité \& Management des Ecosystèmes, Bukavu, RD Congo.

DOI: https://doi.org/10.29121/granthaalayah.v8.i7.2020.426

Article Type: Research Article

Article Citation: Aruna Sefu, Kimenya Musailwa, Bitundu Mwanya Tanya, M'opandu Mondonge, Lwimo Mukenge, Kambale Kavusa Gentil, and Mangambu Mokoso Jean De Dieu. (2020). CLIMATE RISKS ASSESSMENT, OPPORTUNITIES RELATED TO THE EVOLUTION OF ECOSYSTEMS AND LIMITATION OF THE PROVISION OF ECOSYSTEM SERVICES: LANDSCAPE CASE OF SOUTH-KIVU (ALBERTINE RIFLT, DRC). International Journal of Research -GRANTHAALAYAH, 8(7), 98-117. https://doi.org/10.29121/granthaalayah.v8.i7.2020.426

Received Date: 03 June 2020

Accepted Date: 26 July 2020

Keywords:

Climate change

Risk

Valuation

Opportunities

Ecosystem Services

South-Kivu

(C) 2020 The Author(s). This is an open access article distributed under the terms of the Creative Commons Attribution License, which permits unrestricted use, distribution, and reproduction in any medium, provided the original author and source are credited. 
Aruna Sefu, Kimenya Musailwa, Bitundu Mwanya Tanya, M’opandu Mondonge, Lwimo Mukenge, Kambale Kavusa Gentil, and Mangambu Mokoso Jean De Dieu

\section{ABSTRACT}

The analysis and characterization of climate variability over a long five-year period proved fundamental to understanding the impacts of climate change and the vulnerability of ecosystem services in the South Kivu province in the Democratic Republic of Congo. Collection methods from surveys and literature reviews allowed us to conduct qualitative and quantitative analyses of climate change impacts and adaptation approaches based on ecosystem services. For data collection, we used surveys and inventories. The data were statistically analyzed, mainly with regression methods and arithmetic averages. The results of agro-pastoral, fisheries and water production highlight the strong influence of climate change through the decrease in products essential for local consumption. These results are confirmed by statistical analysis almost everywhere $\mathrm{R}^{2}<0.5$ and p-value $>0.05$ (except for vegetable production «p-value < 0.05 », Cereal: $\mathrm{R}^{2}=0.54$ and Legume: $\mathrm{R}^{2}=0.74$ ). The same results show us that the nonregulation of river regimes and the decrease in water production by the appropriate service as a result of precipitation and temperature variability data have led to unprecedented disruption due to negative effects on the ecosystem services analyzed. The proposals of the ecosystem-based adaptation approaches as a solution and are important indicators that have assessed climate risks of ecosystem services combined with the poverty impacts of the population and its environment highly vulnerable to climate change.

\section{INTRODUCTION}

Climate change is a major global challenge, which is increasingly strong on the international scene. Scientific studies clearly show that the changes at work since the beginning of the industrial period are disproportionate to the natural variability of the climate [1], [2]. Since the United Nations Conference on Environment and Sustainable Development, known as the Rio Earth Summit in 1992 and the other various conventions on climate change (Kyoto Protocol in 1997, Paris Protocol 2015, Madrid Protocol 2019), decision-makers around the world have been made aware of the dangers of climate change worldwide. Unfortunately, this multilateral process of managing the climate problem still causes as much disillusionment as it only creates expectations [3], [4], [5], [6].

In Africa, climate and ecosystems impact each other and this has been recognized in various ecozones. This issue has now become a hot topic in forest and wetland environments [7]. Climate change, forests and wetlands are functionally and structurally linked [7], [8], [9], [10].

In the Democratic Republic of Congo (DRC), the climate is marked by moderate interannual variability based on phytogeography systems and chorological. However, it does not escape decadal changes or long-term trends that show effects of climate change. These increases in temperature and rainfall variability also impact the forest lung of six endemic centers and its 17 major plant formations in DRC [11], [12] and are important sources of livelihoods and ecosystem services. But according to USAID [13], they are also threatened by high population and land use, increasing demand for domestic energy and exploitation of non-timber forest products.

The mountainous Kivu region and its surroundings have not been spared the issue of climate variability and change, which are in the news [14]. A few years ago, these events were placed at the center of scientific concerns and provincial and local political decisions because of their immediate impact on nature and its ecosystem services, which are observed on the ground by city dwellers and peasant farmers [13], [15], [16], [17].

For the region under study, the trend observed today shows the decrease in agro pastoral products [14], the water level in Lake Kivu, the supply of water by the company of water supply (REGIDESO) and on fish products have been observed for the last 5 years by this study. This climate fluctuation makes it one of the most serious threats to the achievement of sustainable development goals in this mountainous Kivu region in particular and in the country in general [18].

According to Kabonyi [19] and Mugaruka, et al. [20] these consequences are unprecedented in their intensity, often disproportionately affecting the poorest and most vulnerable populations. These generate visible and undesirable climatic side-effects such as: reduction in agro-pastoral production, floods, soil erosion, landslides and fires in the city of Bukavu and other areas in the region. For example, several previous studies have shown that subSaharan Africa, a bastion of plant diversity for maintaining ecological stability, has shown rainfall deficits in recent decades in terms of rainfall and river and lake water flows [19], [21]. 
It is in this context that the present study on "climate risks assessment, opportunities related to the evolution of ecosystems and limitation of the provision of ecosystem services: landscape case of south-kivu "was initiated to assess the effect of climate variability on the provisioning ecosystem services (direct use) in this densely populated and growing region.

Some authors [19], [20], [22] demonstrate that the vulnerability and adaptability of local communities in South Kivu to problems of water and other ecosystem services are topical issues and a common challenge. This implies an appreciation of the changes recorded in recent years and this is the reason for this study [23]. In response to these adverse actions, the province of South Kivu will have to prepare their urban and rural communities for future challenges related to climate change through easy communication tools [24].

Human well-being in South Kivu in general and its surroundings in particular must depend on the sustainable use of ecosystem services. Currently, unsustainable human activities in South Kivu are becoming threats to terrestrial and aquatic ecosystems, making them fragile, and their distribution is now being invaded by fallow crops and areas reforested with exotic species such as Eucalyptus, which is not conducive to soil conservation [19].

However, this tenderness makes ecosystems unproductive because of human influence with consequences on the scale of local economies [23], [25].

Therefore, the objective of this study is to compare the performance of the provision of ecosystem services such as (water, agro-pastoral products and fisheries) over the last five years affected by ecosystem change due to rainfall and temperature variations that will guide national, provincial and local policy makers to resist and adapt to the impacts of climate change and other stresses such as the degradation of cropland and conservation areas.

With regard to this objective, two questions are asked: are the effects of climate change in South Kivu being felt and understood by the population? And to what degree as among specialists in the field? The problem of climate change is a global reality as outlined above, the effects of which can be observed at all levels of life and presents risks for the various ecosystem services and the economic circuit [5]. This study will help us to prove this scientifically.

The results of this study will also enable us to inform political decision-makers on the strategic orientations of preventive measures put in place and focused against driving forces, responses envisaged for the mitigation of pressures on ecosystems and landscapes, restoration responses adapted to landscapes to limit the state of their degradation and maintain their capacity to provide ecosystem services and prevent adaptation measures in the face of induced impacts.

\section{MATERIAL AND METHOD}

\subsection{STUDY AREA}

Located in the east of the DRC, it occupies about 3\% of the country's surface area, or $65,070 \mathrm{~km}^{2}$, and has a population of about seven million [25], [26]. Livestock, agriculture and trade are the three main activities of this population. It is bordered to the east by Rwanda, the Republic of Burundi and Tanzania; to the north by the province of North Kivu (DRC), to the west by the province of Maniema and to the south by the provinces of Maniema and Tanganyika (DRC). This province is divided into four cities (Bukavu "provincial capital", Baraka, Uvira and Kamituga) and eight territories (Figure 1). 


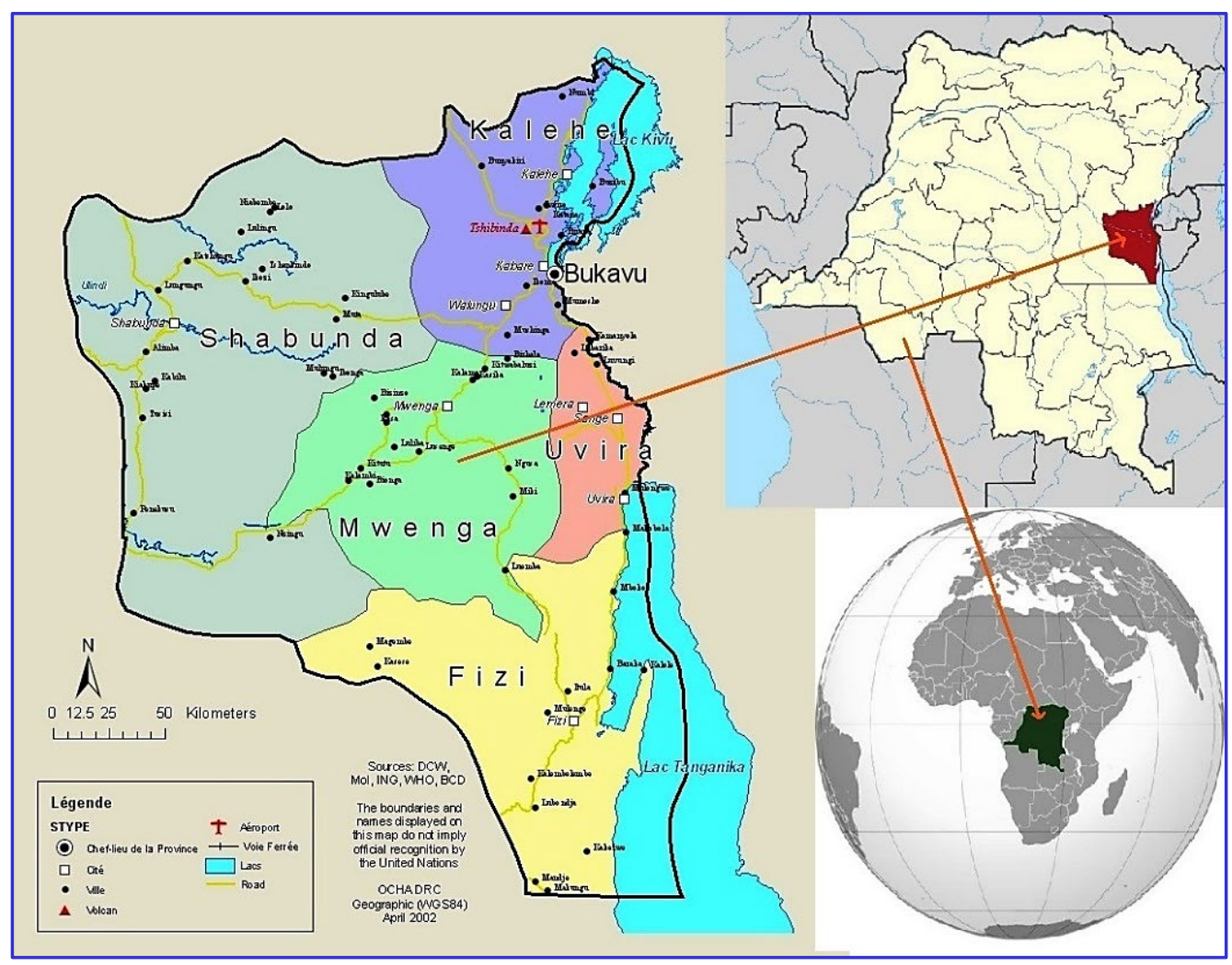

Figure 1: Administrative map of the province of South Kivu (Source, [28]).

Its relief includes mountains of the western Mitumba Ranges, of which the most important mountains are the peaks of Kahuzi (3. $340 \mathrm{~m}$ altitude), Biega (2.700 m altitude; [26]). In the territory of Shabunda and Mwenga begins the Central Basin. To the east, there is a vast plain, the Ruzizi Plain in the territory of Walungu and Uvira, and the highlands suitable for cattle breeding (itombwe tray, [26]).

The climate alternates between nine months of rain and three months of dry season. It is a humid tropical climate. But in general, there are two types of climate: an equatorial climate with rains throughout the year in one part of the province and a tropical climate with a rainy season and a dry season in another part [27]. Average annual temperatures vary between $11^{\circ} \mathrm{C}$ and $25^{\circ} \mathrm{C}$ [28]. Vegetation is composed of low and high-altitude forests, grassy savannas, wooded bamboos and dense forests.

From a hydrographic point of view, South Kivu has two lakes (Lake Kivu and Tanganyika) and large rivers, Elila, Ruzizi and Ulindi, and many of the rivers in almost all the territories. There is a deposit of dissolved methane gas in the deep waters of Lake Kivu; it is estimated at 45 billion cubic meters [29]. There are four hydroelectric power stations: Ruzizi I \& II, Kyimbi (Bendera) and Mungombe. There is an abandoned micro-power plant, the Magembe plant at Fizi [29].

There are large oil deposits in the rocks west of Lake Kivu and others at the bottom of the lake. There are also oil deposits in the Ruzizi Plain and Lake Tanganyika. Explorations are being carried out in Katanga, at the mouth of the Mutambala River in the town of Baraka. Other research is being carried out in Karamba at the mouth of the Nemba River, $25 \mathrm{~km}$ from the town of Baraka in the territory of Fizi, where bitumen, of a hydrocarbon waste product with a carbon concentration of $80 \%$, has already been collected. Peat is also exploited in South Kivu in Kakonda, Kabare territory, and in Nyangezi, Chiherano and Kachandja, Walungu territory.

The province of South Kivu has several tourist sites. The most important are: Thermal waters of Lubugaa, Kavimvira, Katogota, Masuza in Runingu, salt works, sea salt etc. [28], [29].

\subsection{METHODOLOGY}

For this study, we used empirical methods by which surveys and inventories carried out in the field have the most cost-effective scientific relationship [29]. For this paper we proceeded as follows: 
- systematic documentary collection prior to the field survey through qualitative observations (also called indirect observation), questionnaires, sociograms, etc. [30]).

- collection of field data as a reference collection through a literature review using available data [30] in the technical services of the South Kivu provincial government in relation to the ecosystem service sector for a period of five years ( 5 years);

- carrying out qualitative and quantitative analyses of the data collected from these technical services; which are indicators [30], [31] of the impact of climate change and of adaptation approaches based on ecosystem services.

- interpretation of field data in relation to the selected set of documentary data as proposed by [31] and by taking into account the social sources of information production.

- It should be pointed out in passing that these different phases are within the two main stages to which our approach obeyed, i.e. the pre-survey and the survey following certain theories structured around the Driving Forces-Pressure-State-Impact-Response framework, providing an introduction to the concepts, methodologies and techniques relevant to the change that can be observed in an ecosystem [32].

\subsection{DATA ANALYZE}

For the analyses, the data were processed by statistical methods, mainly regression $\left(\mathrm{R}^{2}\right)$, hypothesis testing ( $\mathrm{p}$ value) and indexes of arithmetic means using PAST software [33].

The regression $\left(R^{2}\right)$ is the value between 0 and 1, it is significant if $R^{2}>0.5$ and is rejected if $R^{2}<0.5$ [34], but for p-value called the significance level of the test, traditionally $5 \%$ or $1 \%$ and denoted as $\alpha$. If the $p$-value is less than the chosen significance level $(\alpha)$, that suggests that the observed data is inconsistent with the null hypothesis and that the null hypothesis may be rejected. For typical analysis, using the standard $\alpha=0.05$ cutoff, the null hypothesis is rejected when $P<0.05$ and not rejected when $P>0.05$. The p-value does not, in itself, support reasoning about the probabilities of hypotheses but is only a tool for deciding whether to reject the null hypothesis [34].

The arithmetic mean $(\bar{X})$ : or empirical mean of a statistical series is the ordinary mean [34], i.e. the ratio of the sum $n$ of observations $(x 1+x 2+\ldots \ldots . . x n)$ of a discrete quantitative statistical character by the number of distributions $(n)$ as found in the formula [33].

$$
\bar{X}=\frac{X_{1}+X_{2}+X_{3}+\ldots \ldots . X n}{n}=\frac{1}{n} \sum_{i=1}^{n} x i
$$

When the data are ordered as a frequency distribution [33], the mathematical formula to be applied is as shown below (2):

$$
\bar{X}=\frac{\sum_{i-p}^{p} x_{i} \cdot f}{\sum_{i-1}^{p} f_{i}}
$$

\section{RESULTS AND DISCUSSIONS}

\subsection{SURVEY RESULTS AND INTERPRETATIONS}

The validity and veracity of the data collected for this study began with a pre-investigation, a control of the information, counter-checking and confrontation of the field teams with agricultural producers, breeders, fishermen and with the water distribution company (REGIDESO). 
Aruna Sefu, Kimenya Musailwa, Bitundu Mwanya Tanya, M’opandu Mondonge, Lwimo Mukenge, Kambale Kavusa Gentil, and Mangambu Mokoso Jean De Dieu

\subsubsection{AGRICULTURAL PRODUCTION}

The five-year (2013-2017) agricultural productivity results from the South Kivu Provincial Inspection of Agriculture, Fisheries and Livestock [35] can be found in Graphs (I....IV), in following the page.

\subsubsection{TUBER PRODUCTION}

Our surveys show that cassava (Manihot esculata) production has been the most important crop over the last five years compared to other tubers. According to our interviews with some producers, they testified that this production is justified by the involvement of the technical and financial partners who support the provincial government of South Kivu in combating food insecurity with the improved cuttings and other diseases such as mosaic which are signs of the effects of climate change in the region (Graph I).

Some partner institutions in the provincial government were cited by our respondents, mainly IITA, INERA Mulungu and FAO. This trend is also linked to the eating habits of the inhabitants of the province where cassava is the main staple [36]. Our surveys found that cassava production is followed by colocase (Colocasia esculenta) and potato (Solanum tuberosum). This finding was raised by Ganza et al. [37] who show that its tuber yields adapt easily to tropical and mountain climates. Unfortunately, following the climatic effects crossing the region, sweet potato (Ipomoea batatas), yam (Dioscoria sp) have been largely affected by the effects of natural risk, misuse of land use, various plant pest diseases and changing landscapes in South Kivu ([38]). This result is confirmed by statistical tests, the probability being above the threshold of the null hypothesis and the regression being less than 0.5 (P-value > 0.05 and $\mathrm{R}^{2}=0.2414$ ).

The same threats are observed by Hire et al [39]. According to these authors, a large part of sub-Saharan Africa would be alerted by climate effects in recent years following the increased number of extreme weather events such as waves, increased heat, water submersion, soil droughts, etc., which affect tuber agricultural production in many African regions and even the globe. These events cause drought, shortened vegetation cycle, migration of pests and diseases, fires.

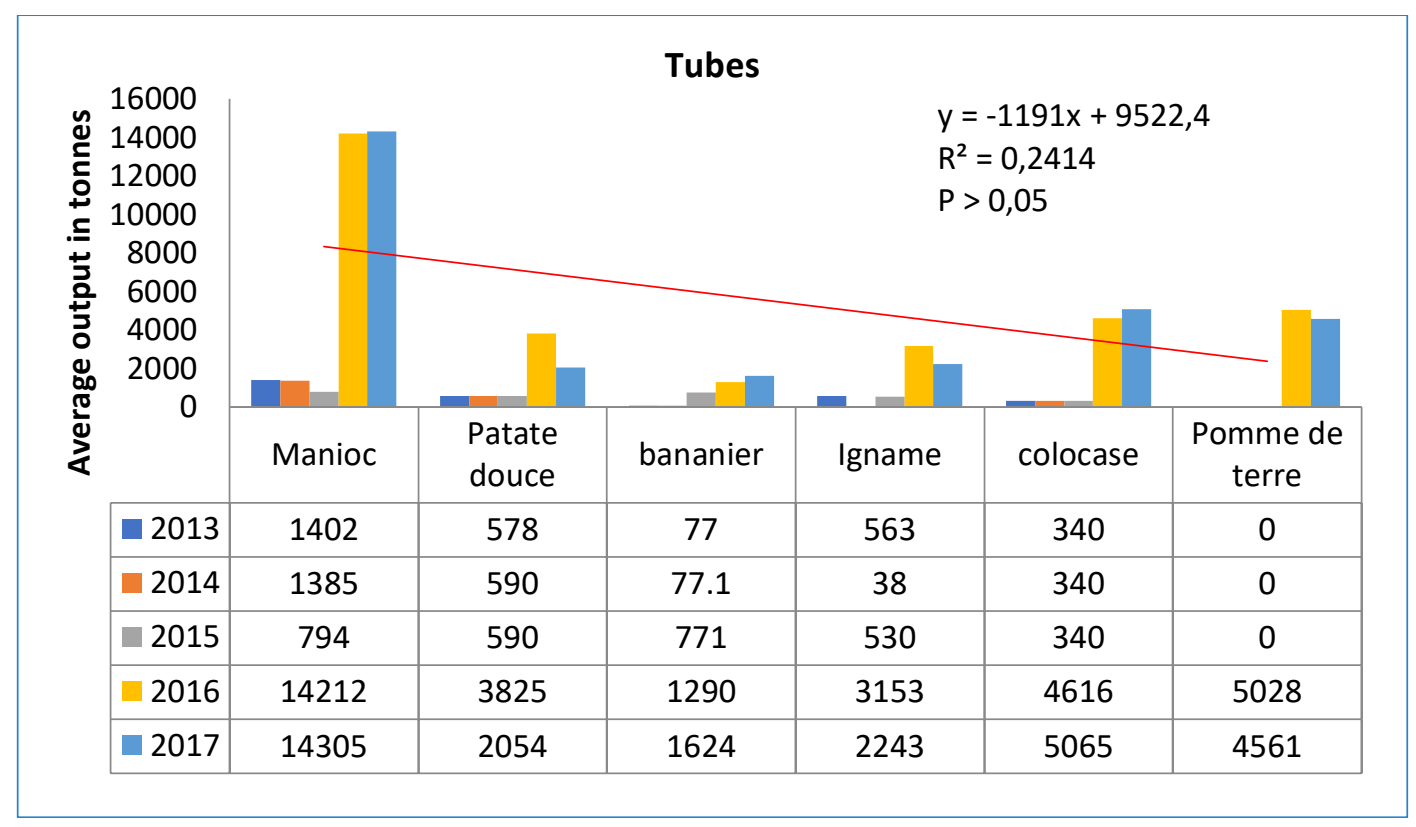

Graph I: Tuber production in South Kivu province during five years of study.

\subsubsection{CEREAL PRODUCTION}

It is considered that the cultivation of cereals has allowed the rise of great civilizations [40]. It was one of the first agricultural activities in the world and in our region, especially in the Ruzizi plain in the territories of Walungu 
and Uvira. In fact, while providing regular and abundant food to the population, cereals allowed the organization of denser and more complex societies [40]. For the region of our study, the results are shown in Graph II.

Based on Graph II of the five-year data (2013-2017) such as corn (Zea mays) and rice (Oryza sativa) compared to other years. This situation is linked to the involvement of the population who make an effort in the irrigated perimeters in South Kivu in some marshlands as an off-season crop. For this reason, the statistical test analyses are above the threshold (P-value $<0.05 ; \mathrm{R}^{2}=0.54$ ).

Reason why the wise management of wetlands in South Kivu would make an important contribution to limiting the effects of climate change. Over the last three years (2013-2015), cereal supply has been largely affected by the effects of climate and this has increased the malnutrition rate, which reached $53 \%$ among children under 5 years of age and pregnant women in the study area in 2016 [41]. The current security situation in the highlands and middle plateaus of the Fizi-Uvira territories and Kalehe would also have influenced the yield of certain cereals such as maize (Zea mays) which is the most cultivated in these areas and currently affected by armed conflicts and repeated looting, population displacement and house fires [14].

However, this practice of irrigated cultivation was almost non-existent in several wetlands in the South Kivu region that are considered sacred areas by some tribes in the province. From a scientific point of view, recent studies show that these areas are mostly composed of peatlands which play an important role in carbon sequestration [42] in DRC and Central Africa [43].

Based on Graph II of the five-year data (2013-2017) from the office in charge of cereals of the South Kivu Provincial Inspectorate of Agriculture, Fisheries and Livestock in its 2018 [35], our investigations revealed a strong increase in the production of cereals during the last two years (2016-2018). Some authors, such as Wood et al [8], argue that the exploration of wetland-based livelihoods should be considered in the DRC according to the needs and development aspirations of local people, and would seek to determine how these can be achieved alongside the sustainable functioning of ecosystems and the ecosystem services they provide.

However, Tinker et al. [36] have noted that knowledge of the concept of ecosystem services and ecosystem functioning is still vague, unclear and imprecise at the level of producers and political decision-makers. This situation leads to the consequence of poor management of certain marshes and irrigated areas, currently induced by the absence of regulations defined at both national and local levels. To avoid these new practices used in conservation areas, we suggest applying the Ecosystem-based Adaptation (EbA) to wetland management, which requires adaptive management to fully understand the dynamic and complex nature of particular ecosystems, including a complete knowledge or understanding of their functioning by users [43], [44].

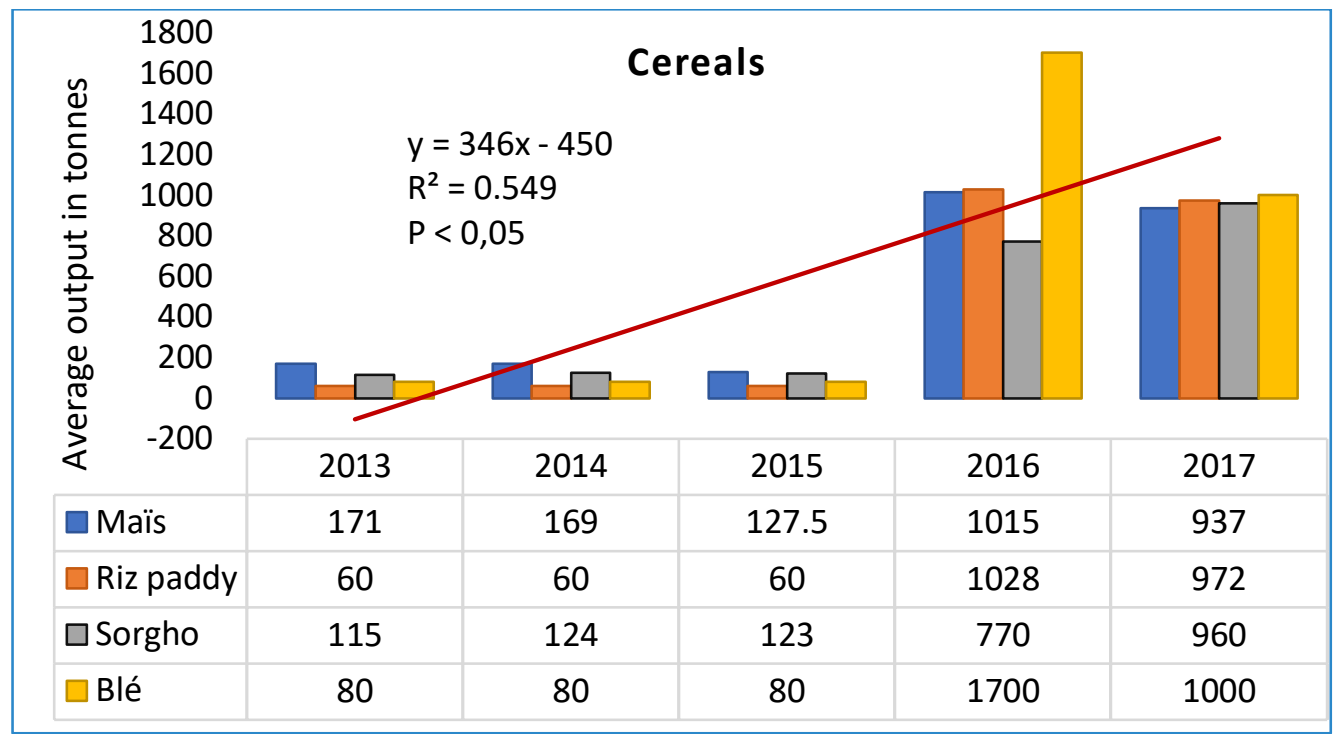

Graph II: Tuber production in South Kivu Province during five years of study.

This approach is considered a winning formula for sustainability in the face of global warming. Several environmental agreements recognize that ecosystem depletion limits the capacity to adapt to climate change and that ecosystem-based approaches (EbA) to adaptation should be used as a priority. This approach has the potential 
Aruna Sefu, Kimenya Musailwa, Bitundu Mwanya Tanya, M’opandu Mondonge, Lwimo Mukenge, Kambale Kavusa Gentil, and Mangambu Mokoso Jean De Dieu

to increase the adaptive capacity of local communities to build social and ecological resilience to climate change in developing countries.

\subsubsection{VEGETABLE PRODUCTION}

Vegetable production (Legumes) are rich in nutrients [44], [45]. Legumes are economically accessible and contribute to food security at all levels and are seasonal crops. They contain about twice the amount of protein found in cereals, such as wheat, maize, rice,... [47]. Legumes are more advantageous because they not only adapt to climate change but also contribute to mitigating its effects due to their capacity to fix nitrogen in the soil [48].

According to FAO [48], hundreds of legume varieties, including many legume species grown around the world, are essential components of soil management and pest control at the farm level, especially at the smallholder level. An important property of legumes is their ability to biologically fix nitrogen. These plants, in symbiosis with certain types of bacteria (e.g. Rhizobium, Brady rhizobium), are able to convert atmospheric nitrogen into nitrogen compounds that can be used by plants, also improving soil fertility. Some legume species are also able to release phosphorus from the soil, which also plays an important role in plant nutrition [47], [48]. Legumes are staple foods in South Kivu province such as beans (Phaseolus vilgaris), soybeans (Glicine max), peanuts (Arachis hypogaea) and peas (Pisum sativum), Graph III. The results obtained from our surveys can be found in graph three below. According to Graph III, the data collected for the last five years, 2013-2017, from the office in charge of legumes of the Provincial Inspection of Agriculture, Fisheries and Livestock of South Kivu [35], we can see that the five-year average among these legumes, soybeans occupy the first position, followed by beans and peas. Regardless of climate change, vegetable production is still higher, and vegetables are staple foods for the majority of families. This was confirmed by the results of statistical analyses $\left(\mathrm{R}^{2}=0.74\right.$ and $\mathrm{P}$-value $<0.05$

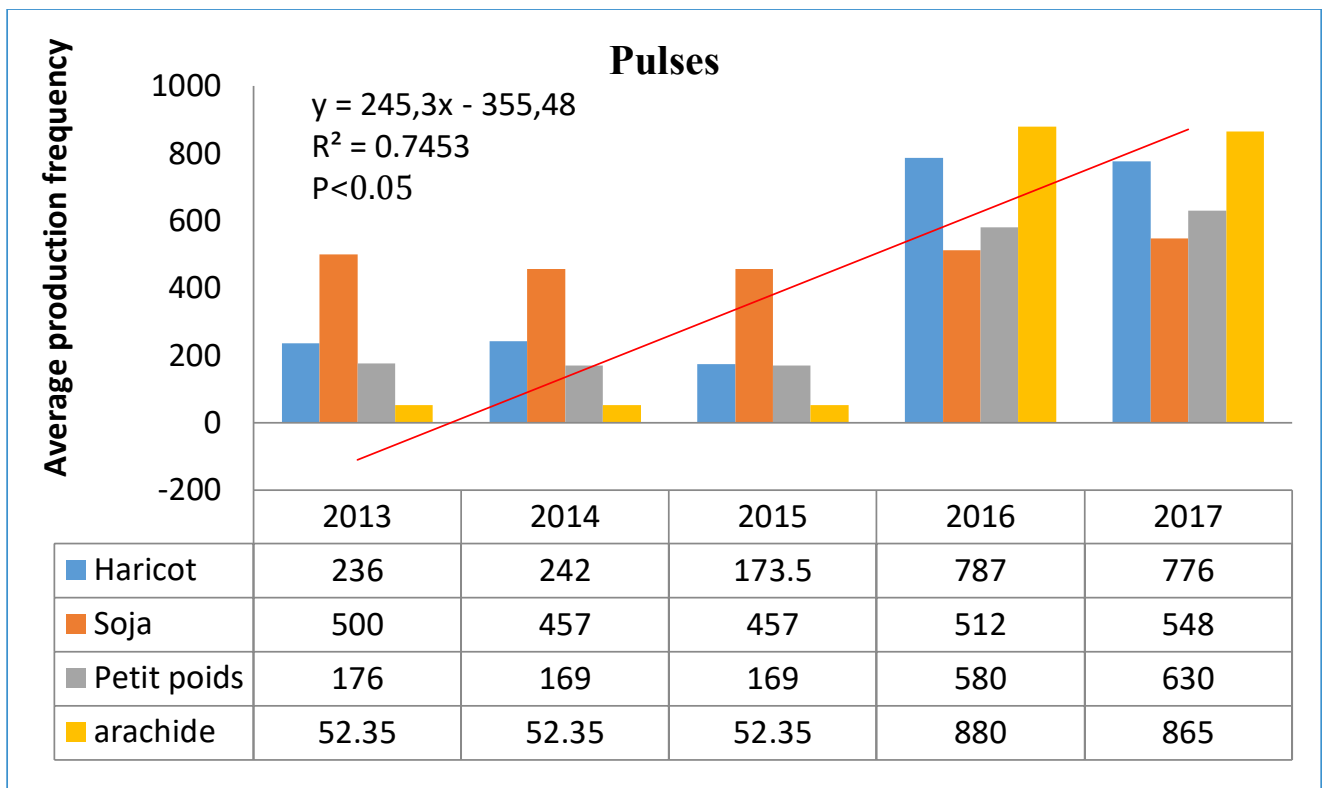

Graph III: Tuber production in South Kivu Province during five years of study.

The presence of legumes in agricultural ecosystems in South Kivu helps to maintain and/or to increase the biomass and microbial activity vital to the soil already degraded by human actions and climate change and feed organisms responsible for promoting soil structure and nutrient availability. Abundant soil biodiversity not only provides ecosystems with the capacity to resist and be resilient to disturbances and stresses, but also improves their ability to eradicate diseases.

Unfortunately, as a result of climate change and seasonal disturbance, production has declined significantly in the last five decades after independence. These constants are remarkable in other provinces of DRC and in the legume-producing zones in Great Lake region. 


\subsubsection{FISHERY PRODUCTION}

In South Kivu, fishing is one of the activities practiced by the riverside people living along Lake Kivu and Tanganyika. These lakes are shared between the DRC on the one hand and neighboring countries on the other in the world. Fishing activities are limited according to the so-called Congolese and neighboring areas.

The fishermen exploiting these lakes claim that this activity helps them to provide for their families. For the elders, they are able to provide for the necessities of life through what they earn from fishing, which has become their daily work. In relation to production, fishermen used to be able to evaluate the quantity produced in terms of kilos, but nowadays the evaluation has totally changed due to the disturbance of spawning grounds, pollution of the lakes...and failure to respect the closure period [49].

Graph IV illustrates data collected for the last five years, i.e. from 2013-2017, from the office in charge of fishery products of the South Kivu Provincial Inspectorate of Agriculture, Fisheries and Livestock in its 2018 report. Our survey reveals that the increase in fish production of species such as Limnothrica sp (commonly known as Sambaza) on Lake Kivu in 2015 with a declining trend towards the last two years i.e. 2016-2017.

According to our interviews with fishermen's associations, the decrease in production stocks in the bays of Lake Kivu and Lake Tanganyika is explained by the poor occupation of the littoral zones of these two lakes and the poor management of its watersheds affecting changes in these ecosystems. This was confirmed by the results of statistical analyses (P-value $>0.05$ and $\mathrm{R}^{2}=0.39$ ).

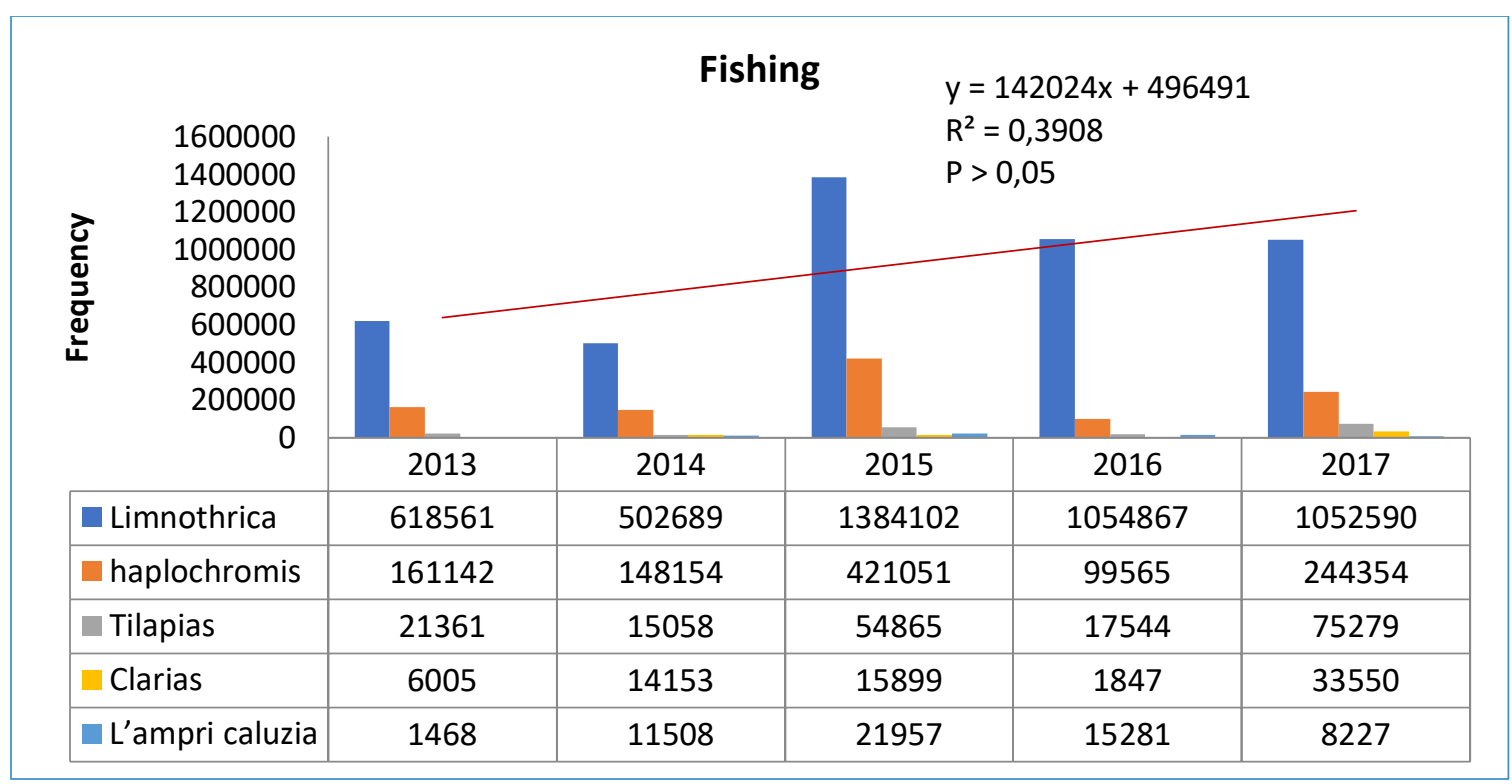

Graph IV: Tuber production in South Kivu province during five years of study.

A study by Masilya [50] indicates that the degradation of the littoral zones of Lake Kivu would affect the yield of certain species. Our results provide sufficient evidence that the effects of climate accompanied by human pressures on this large basin have affected certain species such as Tilapia and clarias, whose stock in terms of production has greatly decreased according to data from 2013 to 2017. Akonkwa [49] suggests the need to undertake adequate development measures for the safeguarding and sustainable management of these aquatic resources.

\subsubsection{SMALL LIVESTOCK BREEDING}

According to Kibwana et al. [51] in the humid tropical highlands of East Africa, small livestock systems are extensive or semi-intensive, on grazing land. Smallholder livestock production in South Kivu is of particular importance and is an important source of food security and income (job creation) for the population [52].

Graph V shows us the trend in the breeding of small livestock collected during the last four years, i.e. from 20142017, from the office in charge of animal production at the Provincial Inspection of Agriculture, Fisheries and 
Livestock of South Kivu [35]. Our investigations reveal that the domestic goat (Capra aegagus hircus) is in first place followed by the guinea pig (Cavia porcellus) despite slight decreases in their products observed for the last 4 years of available data, i.e. 2014, 2015, 2016 and 2017. Species such as pigs (Sus scrofa domesticus) and domestic rabbits (Orytolagus cuniculus) have been affected. However, according to [16], the products of cows (Bos taurus) and sheep (Ovis aries) have been the most affected following the proliferation of diseases, some of which are linked to the effects of climate change and loss of plant cover. This result is confirmed by statistical tests, the probability being above the threshold of the null hypothesis and the regression being less than 0.5 ( $\mathrm{P}$-value $>0.05$ and $\mathrm{R}^{2}=0.0402$ ).

On the other hand; Akilimali et al. [53]. The study, however, notes that some livestock products such as pigs in South Kivu are characterized by poor production performance and degeneration of local breeds, and lack of education among unsupervised farmers. Knowledge of the socioeconomic characteristics of the herders, the determination of the main breeding systems, production performance and the main constraints facing production in South Kivu province are important bases for considering its further improvement [53].

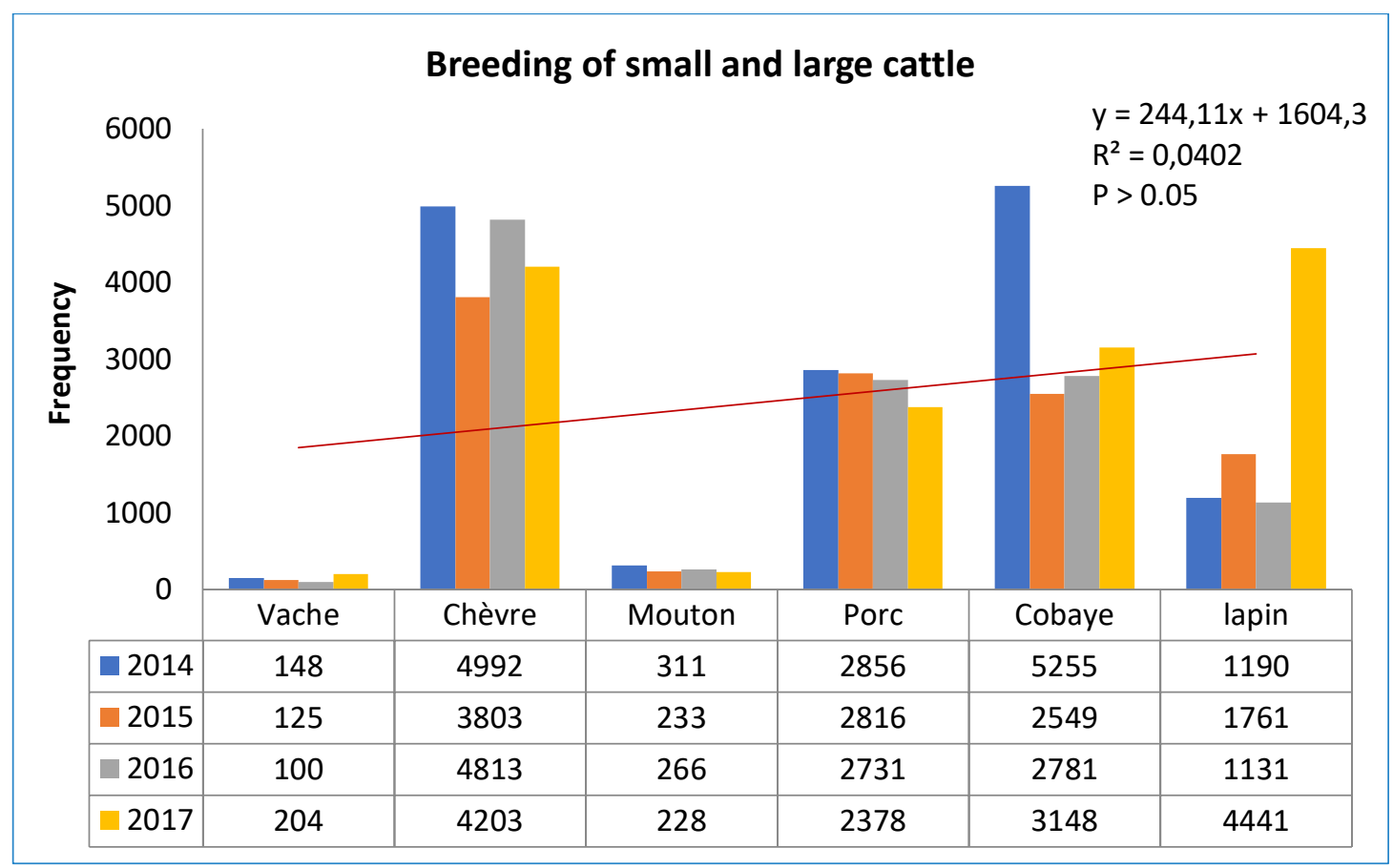

Graph V: Tuber production in South Kivu Province during five years of study.

\subsubsection{WATER PRODUCTION BY THE WATER DISTRIBUTION COMPANY}

Global and gradual warming of the planet is thus closely linked to contemporary lifestyles, production and consumption patterns, and has a direct impact on ecosystems and societies. Water is at the heart of these changes, as the observations and projections of the main scientists gathered around the Intergovernmental Panel on Climate Change (IPCC) demonstrate [45].

The hydrological cycle is affected in all its aspects by climate change: changes in rainfall patterns, runoff, sea level rise, desertification processes, etc. The water cycle is affected in all its aspects by climate change. Water resources are threatened and affected in many regions, with impacts on all areas of development (access to water, food security, health, etc.), while the risk of water-related disasters will increase. Those who feel the impacts of these changes most will be the most vulnerable [45]. In South Kivu, water no longer flows regularly at the taps, according to an observation made by Aruna [46], in some urban areas. In some catchment sources, production plants no longer have the capacity to cover the population's drinking water needs, i.e., rehabilitated springs.

The data in graph VI of the data collected for the last 6 years, i.e. from 2012-2017, at the commercial service of the Distribution water company (REGIDESO) South Kivu in its 2018 report, show that; the supply of water in the city of Bukavu, shows a downward trend and would be linked to climatic factors and the degradation of forests and 
landscapes that have affected the aquifer which no longer has the capacity to supply the quantity of water that can cover the needs of the population in the city of Bukavu. Aruna [46], gives a scientific statement that, from a scientific point of view, the permanent lack of water has its origin in the main phenomena such as: landscape degradation and desertification. Both of these factors depend on man, who has impoverished the soil and this affects groundwater. The biggest problem is that the population does not know the three thresholds defined as alert or constraint thresholds or the critical shortage threshold in m3 /capita/year [45] REGIDESO should make this information known to the population at all times in order to develop adaptation strategies.

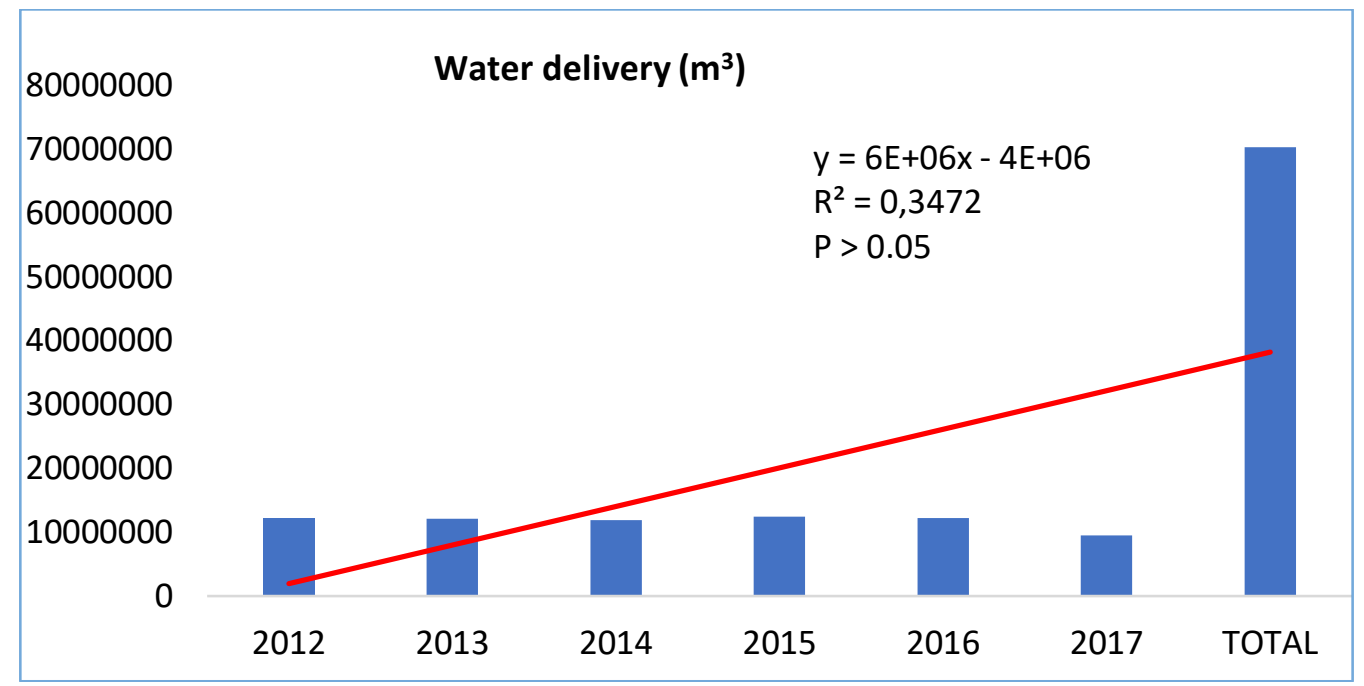

Graph VI: Delivery in $\mathrm{m}^{3}$ of water by REGIDEO

\subsubsection{RAINFALL VARIABILITY DATA}

In the South Kivu region, climatic degradation has led to a shift in isohyets from north to south with changes in temperature from one year to the next [19]. The spatial representation of rainfall has made it possible to see the spatial evolution of isohyets over the years and thus characterizes the rainfall dynamics in the region. The Graphs below present just the monthly rainfall fluctuations for the last three (3) years in South Kivu according to the Report of the Centre of research of natural sciences of Lwiro, Graph VII \& VIII).

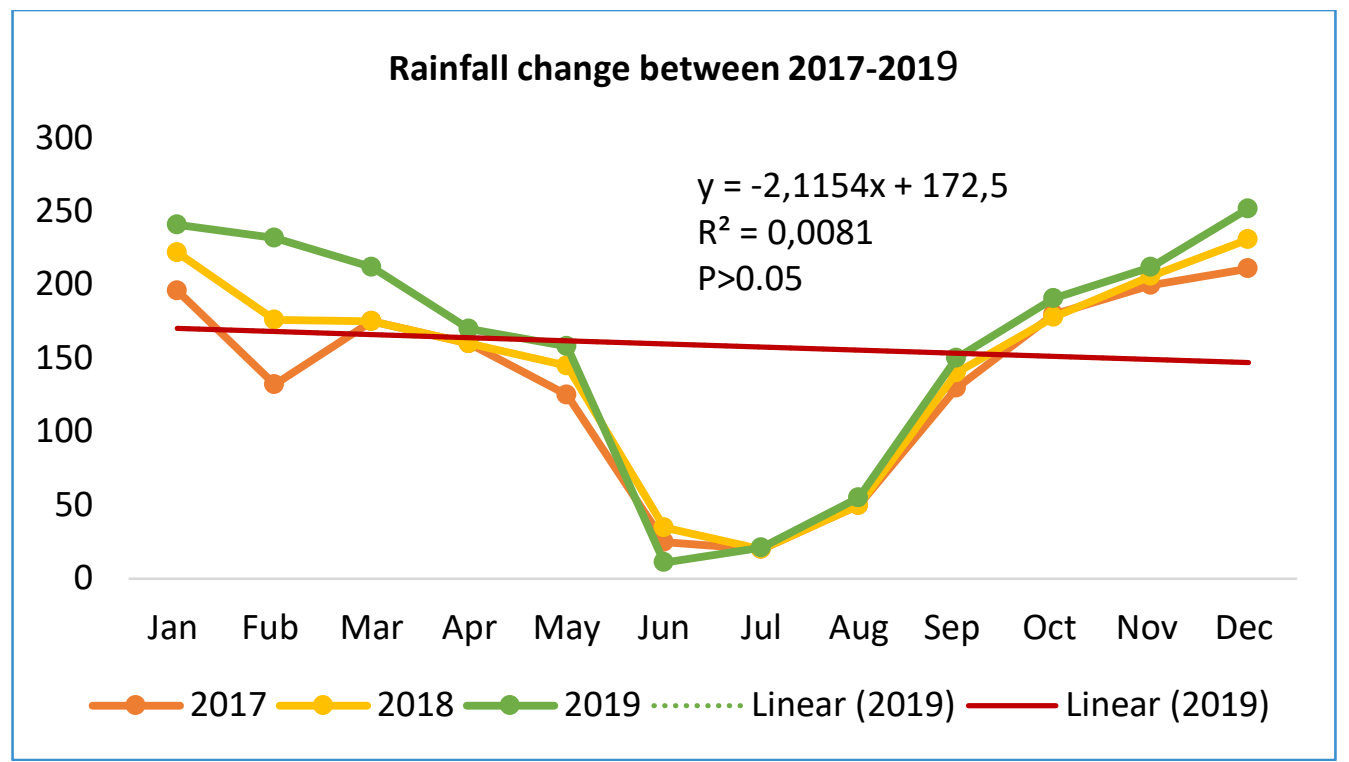

Graph VII: Rainfall change between 2017- 2019. 

and Mangambu Mokoso Jean De Dieu

This brief presentation of these data allows our reader to better perceive the variations induced by climate change in the region of study. In fact, seasonal variability in rainfall and temperature has significant consequences on agricultural production, plant cover, etc., and is a major factor in the development of the region's economy. Observation of the graphs shows that there is some disparity in the distribution of monthly temperatures [16], [25], [36]. This is true for all stations. The dry months during which some isolated precipitations are observed are more or less affected by the rise in temperature. This justifies that abnormal months vary between 3 and 4 months. This was confirmed by the results of statistical analyses $\left(P\right.$-value $>0.05 \& R^{2}=R^{2}=0.0081$ of Rainfall change between 2017- 2019 and $P$-value $>0.05$ and $R^{2}=0.14$ of temperature change, Graph VII \& VIII). This proves that there is a problem of climate disruption that will require a long period, governance and significant resources to restore this landscape that has been disrupted by unsustainable uses.

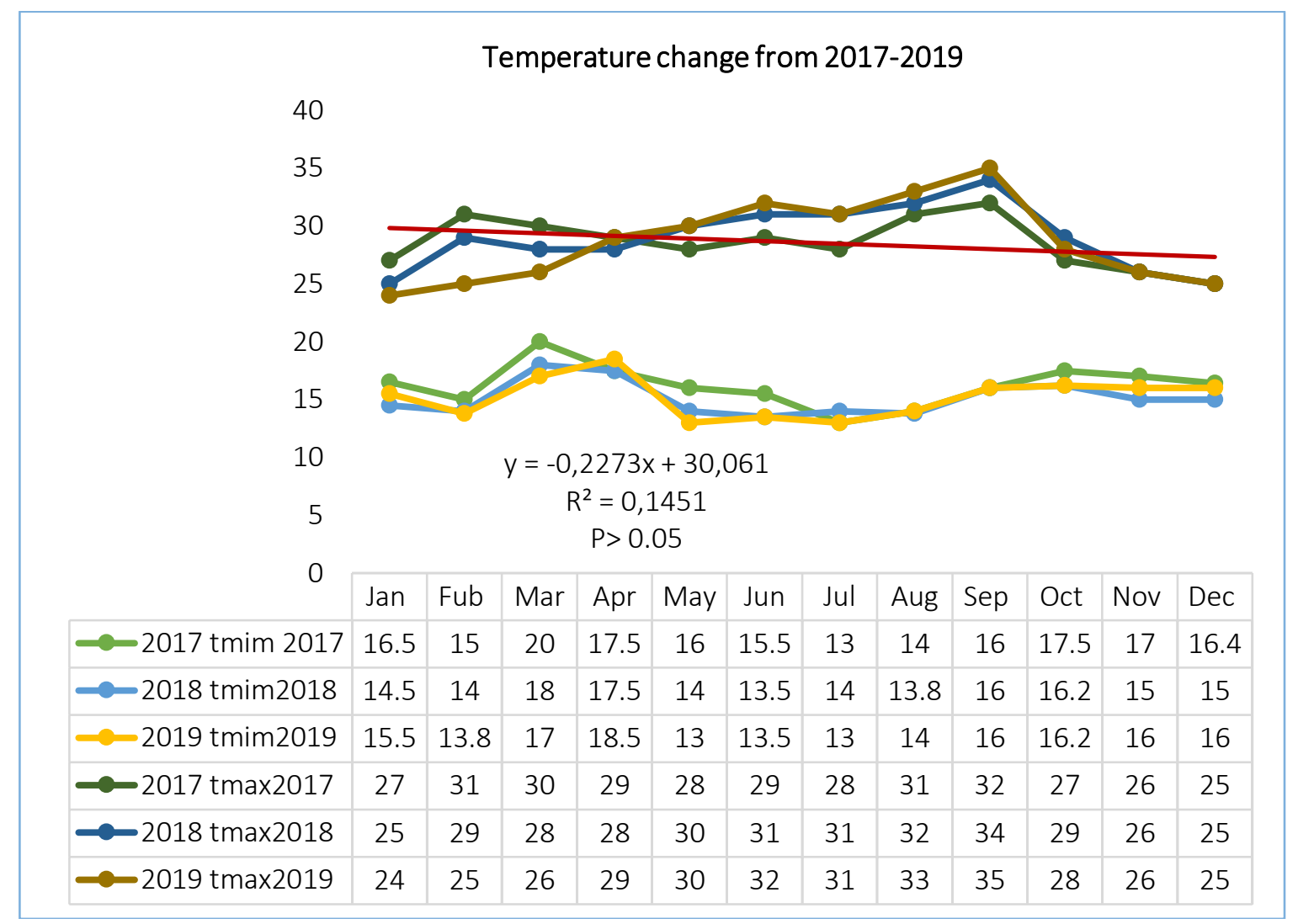

Graph VIII: Temperature change from 2017-2019.

\subsection{THE CONCEPTUAL FRAMEWORK: AN ADAPTED DPSIR MODEL}

For this study, the conceptual framework we used is a DPSIR (Driving Forces, Pressures, States, Impacts, and Responses) model adopted by the European Environment Agency. This concept helps us to understand the conditions of Pressures and Driving Forces conditioned by society on nature. These Pressures and Responses act on the situation, the state of the components of nature reacting to the Pressures and Responses by Impacts in return (Impacts-I) to the population. These impacts can be observed in the form of variations in the ecosystem services provided: food, water regulation, soil fertility, etc ${ }^{1}$. This model (figure 2) has allowed us to understand the development of a "cause-effect" relationship to link climate factors and their effects, and to establish a link between the different elements that directly or indirectly influence the state of performance of ecosystem services. These are referred to as "causal" or "relational" models, [57]. »

${ }^{1} \mathrm{http}: / /$ indicateurs-biodiversite.naturefrance.fr/fr/le-cadre-conceptuel-un-modele-dpsir-adapte 
Taking into account the impacts, allows to integrate the repercussions of the Pressures, beyond the physical, chemical or biological aspects. This has enabled us to integrate all the stakes of the degradation factors beyond the observed/measured situation by considering the impact on humans and their activities, at different spatial and temporal scales in the South Kivu province.

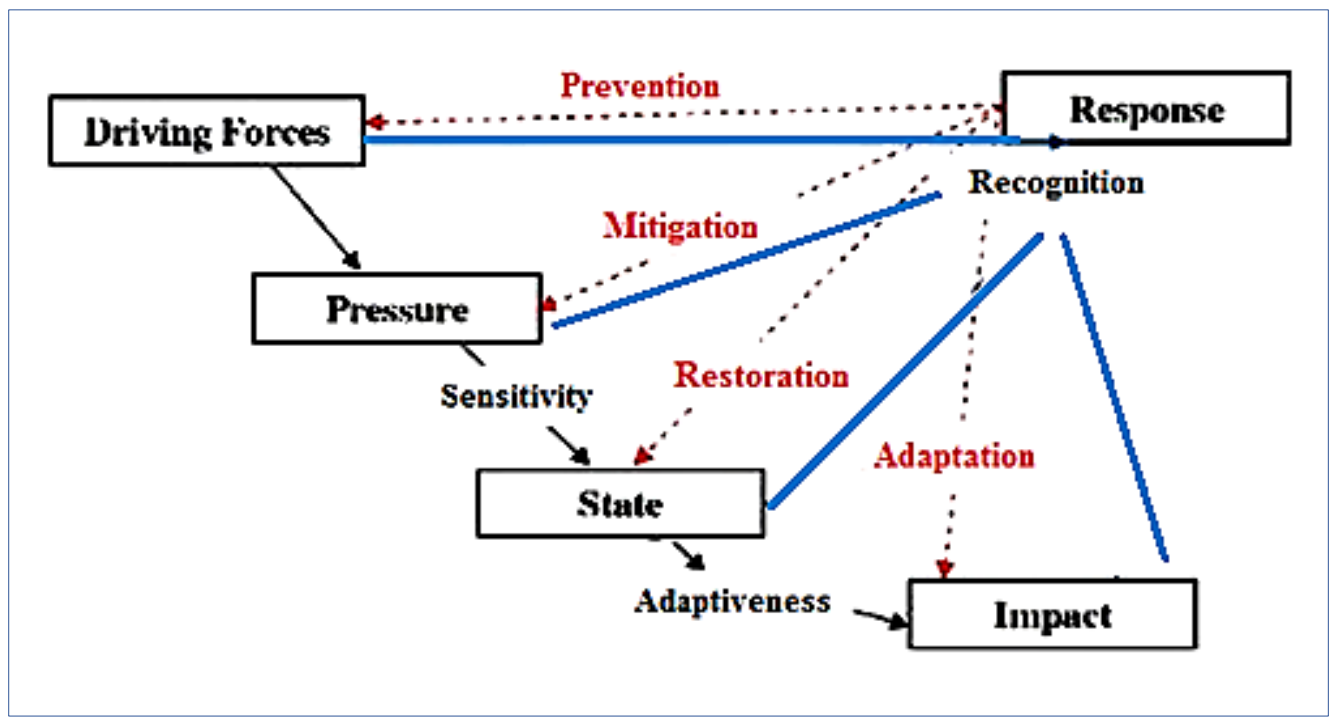

Figure 2: Diagrams of the conceptual framework of a DPSIR model (Salehio et al., [57]).

Legend: The Responses (R) correspond to what is implemented to remedy the observed situation, i.e. corrective actions/provisions implemented at different scales and in different forms (curative/preventive, regulation/prohibition,....; political measures, collective initiatives, behavioral norms, etc..., [57]). The responses must ultimately serve to inform the actors and the public [58].

\subsubsection{PRESENTATION OF THE ECOSYSTEM-BASED APPROACH TO ADAPTATION (EbA).}

According to some researchers [59], Ecosystem-based adaptation (EbA) is used by a number of organizations and in many developed and developing countries as a means of climate adaptation, particularly at the community level. This approach is also used to reduce disaster risk. It is currently considered a winning formula for sustainability in the face of global warming. Several environmental agreements recognize that the depletion of ecosystems limits the capacity to adapt to climate change and that ecosystem-based approaches (EbA) to adaptation should be a priority for states, as this approach has the potential to increase adaptive capacity and social and ecological resilience. It should be noted that very often these visions discussed in the climate negotiation rooms are not translated into concrete targets and hardly involve local communities ${ }^{2}$.

This is why our research focuses on measures to increase the acceptance of the ecosystem-based approach (EbA) to adaptation in the DRC government's action plans in terms of expected contributions determined at the national level. However, in order to evolve well in the context of climate change in the DRC our approach is one that encourages a bottom-up direction while building resilience capacities. It is in this way that the Ecosystem-Based Approach (EbA) to adaptation must be implemented through participatory community-based approaches.

\subsubsection{THE GOVERNANCE STRATEGY FOR AN ECOSYSTEM-BASED APPROACH TO ADAPTATION (EbA)}

Governance as the norms and processes that determine how a society exercises power, allocates responsibilities and makes decisions to protect, sustainably manage and restore ecosystems. It is within this framework that a local

${ }^{2}$ www.iied.org/ecosystem-based-adaptation 
Aruna Sefu, Kimenya Musailwa, Bitundu Mwanya Tanya, M’opandu Mondonge, Lwimo Mukenge, Kambale Kavusa Gentil, and Mangambu Mokoso Jean De Dieu

strategy for adapting to climate impacts is proposed in this study. However, this governance will have to be flexible, multidimensional, respecting issues of equity and transparency, and be based on a full understanding of the potential and needs of ecosystems [60].

\subsubsection{ADAPTIVE GOVERNANCE IN SOCIO-ECOLOGICAL SYSTEMS}

In the context of EbA governance, the connections and interdependencies between humans, livelihoods, ecosystems and their services need to be taken into account to the extent that they are linked in social ecological systems (SES), [6] (Figure 3). As an emerging form of environmental governance, adaptive governance is increasingly being called upon by practitioners to coordinate resource management regimes in the face of the complexity and uncertainty associated with landscape changes related to climate risks [40].

This governance is defined as "the set of interactions among actors, networks, organizations and institutions that emerge in the pursuit of a desired state for socio-ecological systems"[6], [40]. The concept of adaptive governance does not apply exclusively to the governance of socio-ecological systems. However, it is gaining importance and often resonates in the context of natural resource management and climate change adaptation projects, which aim to strengthen the resilience of socio-ecological systems.

To define the appropriate governance structure for the application of the ecosystem approach (EbA), we need to understand the social system of the ecosystem (SES), the functions and services provided by the ecosystem, and the values and benefits that stakeholders receive as a result of the existence of an ecosystem.

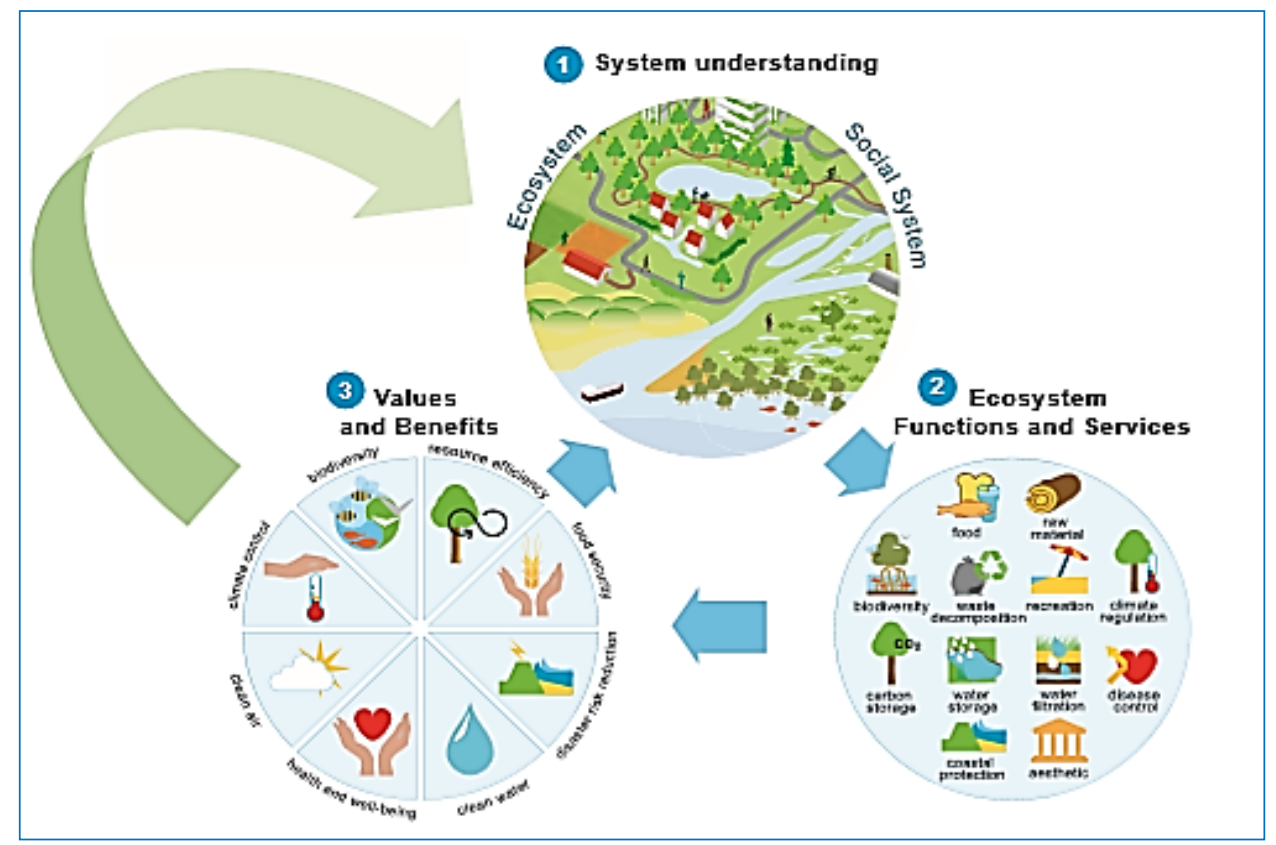

Figure 3: Social-ecological systems (SES) and EbA governance. [61].

\subsection{FUTURE PERSPECTIVES ON THE GOVERNANCE OF THE ECOSYSTEM-BASED APPROACH TO ADAPTATION}

Ecosystem-based Adaptation (EbA) governance must go beyond government and can only work if civil society and the private sector are involved, with clear roles and mandates for action, as defined below [58], [59]:

- that the state plays its key role in creating an enabling political, legal and economic environment for adaptation and climate risk reduction while establishing the governance framework. It is essential to engage society as a whole and its different groups in the governance of EbA and to include the principles of good governance in relevant policies and actions.

- that civil society continues to mobilize people in policy development and governance. The local community and indigenous people are key actors and rights holders; they must defend their rights and 
Climate Risks Assessment, Opportunities Related to The Evolution of Ecosystems and Limitation of The Provision of Ecosystem Services: Landscape Case of South-Kivu (Albertine Riflt, Drc)

needs with the State but also with the private sector. They can do so through civil society using different media channels or interest groups such as NGOs, community-based organizations or indigenous associations. As a member of civil society, academia will need to continue to provide scientific expertise for policy development and informed decision-making.

- the private sector, which is a key player in EbA governance. Financial institutions, mining companies and other investors, producers, retail traders etc., can provide input on cost-benefit and efficiency. They can provide the inspired framework and/or financial means for the emergence of innovations, or use pressure or incentives put in place by government to encourage compensation. New policies defining policies for payments for ecosystem services should be developed in South Kivu province in DRC, in order to prepare for the implementation of EbA on the national territory.

\subsection{PILOT PROJECT FOR THE RESTORATION AND SUSTAINABLE MANAGEMENT OF THE MOUNTAINOUS AGRICULTURAL ECOSYSTEMS OF SOUTH KIVU (RGEM), AS A MODEL FOR TESTING THE APPLICATION OF EbA IN DRC.}

The government of the DRC has obtained funding from the Global Environment Facility for a period of 5 years. This project is a child project to test the future implementation of ecosystem-based approaches to adaptation in the DRC and specifically in the province of South Kivu in the Kabare territory in the Kabare chiefdom and in the Walungu territory in the Ngweshe chiefdom (figure 4).

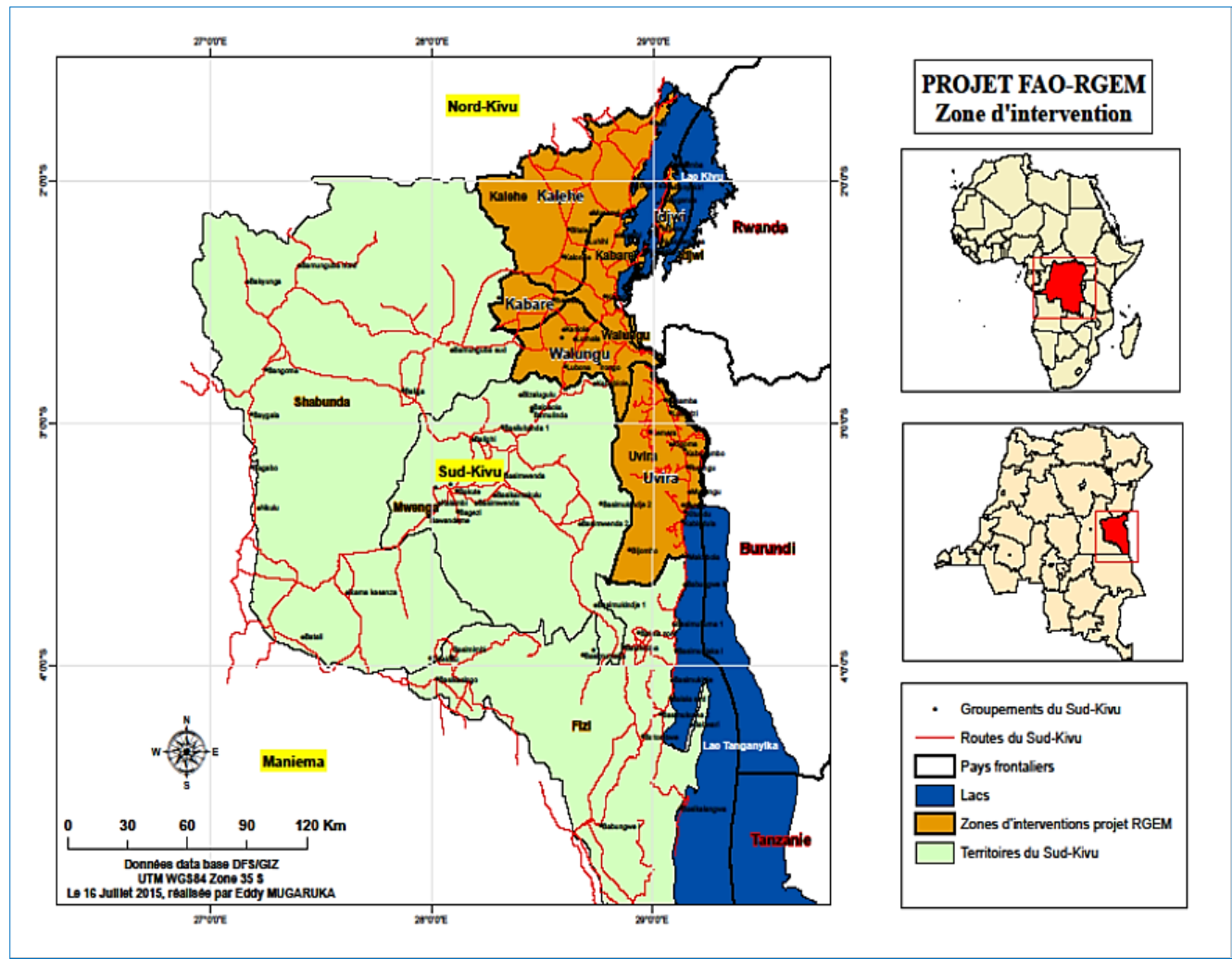

Figure 4: Model for testing the application of Ecosystem-based Adaptation (EbA, [40]).

The choice of these two experimentation areas is justified by natural factors such as climatic disturbances, heavy rainfall and acid precipitation, floods, landslides and the extreme temperatures that were observed in this area during the feasibility assessment of this project. In addition to these natural factors, there are other anthropogenic factors such as demography, poor farming practices, poor natural resource exploitation practices, cultural factors, armed conflicts, uncontrolled urbanization, poor livestock husbandry practices, mining operations, poor supervision and agricultural extension, and a weak legislative framework. 
Aruna Sefu, Kimenya Musailwa, Bitundu Mwanya Tanya, M’opandu Mondonge, Lwimo Mukenge, Kambale Kavusa Gentil, and Mangambu Mokoso Jean De Dieu

The overall objective of this project is to reverse the trend of degradation of soil and biological resources in the mountainous areas of South Kivu. This is for the sustainable increase of plant and animal production, mitigation and adaptation to the effects of climate change

\subsubsection{THIS PROJECT HAS FOUR COMPONENTS, NAMELY ${ }^{3}$}

COMPONENT 1: Improvement of the policy and legal framework taking into account (the South Kivu land-use plan in line with the national strategy, the strengthening of the regulatory framework (provincial decrees and orders) to facilitate the restoration process, support to environmental civil society for an FLR (Forest Landscape Restoration) observatory and the strategy for the restoration of forest landscapes in the province of South Kivu).

COMPONENT 2: Implementation of the Forest Landscape Restoration initiatives and complementary activities of 3 systems (forestry, agriculture and livestock). For the reforestation system: the program foresees the planting of utility trees at the edge of the Kahuzi-Biega National Park (KBNP) as caterpillar trees, melliferous trees, energy, fodder. For the wood energy economy, there will be the development of improved fireplaces. The securing of land tenure rights in the forests of local communities is planned. All this will be accompanied by the development of a simple natural resource management plan at the community level.

For the agricultural system: the project provides for the establishment of water and soil conservation infrastructure (erosion control, terracing, watersheds and hydro-agricultural development). Community capacity building on the introduction of improved agricultural practices for better resilience to climate change (climate-smart agriculture): 0 ploughing, soil fertilization with organic fertilizers, water and soil conservation techniques, etc. The development of the agricultural value chain and support to farmers' organizations will be experimented.

With regard to the livestock system: the project provides for the restoration, fodder improvement and sustainable management of pastures, support for small family livestock (resistant brood stock: goats, poultry), support for the animal health system and the value chain for farmers' organizations.

COMPONENT 3: institutional capacity, finance and scale-up. The program includes support to the National Forest Fund in South Kivu and institutional support to the Sustainable Land Management and Sustainable Development divisions. This policy dimension integrates capacity building for monitoring and measurement to capture environmental benefits (ecosystem services) in the landscape.

COMPONENT 4: knowledge, partnership, monitoring and evaluation. The project integrates the restoration modules into the university and technical education curriculum and the development of tools to raise children's awareness. The landscape restoration program is one of the strategies adopted by humanity for Africa in an attempt to implement the application of the ecosystem-based approach to adaptation. This program is being implemented in Africa to test the restoration of the balance between the ecological, social and economic benefits of forests [61]. This can be done through a land-use model that seeks landscape-wide impacts to stimulate local economic development with more sustainable livelihoods [62]. Involvement of local stakeholders in decision making and the use of existing knowledge is essential.

\section{CONCLUSION}

Climate change is a global problem that links the destiny of mankind excellence with that of his surrounding environment. For this study, it was necessary to carry out a systemic reflection, which is the only way to highlight the interrelation and interdependence between the quality of the environment and human life. These climatic upheavals have significant consequences in the province of South Kivu, exacerbating the phenomena of submerged disturbances in the agro pastoral production system, water, fishing and livestock products.

The vulnerability, resilience and adaptation of the inhabitants in the face of the transformations were documented in this study and the results allowed us to develop certain strategic orientations that essentially addressed local issues related to the exploitation of natural resources in South Kivu and the benefits derived by the communities from the impacts of climate change. The objective of this study was to compare the performance of the

\footnotetext{
${ }^{3}$ Gestion durable des Ecosystèmes agricoles Montagneux du Sud Kivu, FAO (Sud-Kivu), wwwFAO-CD@fao.org
} 
provision of ecosystem services such as (water, agricultural products, fisheries and livestock) over the last five years affected by climate change-induced ecosystem change, and to guide decision makers in developing local policies to resist and adapt to the impacts of climate change and other stresses such as land degradation.

With regard to this objective, our results allowed us to understand that the population does not have the same level of understanding of climate change and how this affects ecosystem change. We believe that the results of this study will be used as communication tools to raise community awareness and will help inform policy makers on the strategic orientations of the preventive measures policies put in place against driving forces, responses envisaged for the mitigation of pressures on ecosystems and landscapes in South Kivu.

According to this study, this will make it possible to limit the state of degradation and maintain the capacities of the ecosystems playing their function as providers of ecosystem services while preventing adaptation measures in the face of induced impacts, as demonstrated in our results, which constitute reference indicators in South Kivu in a complex ecosystem dynamic.

\section{SOURCES OF FUNDING}

This research received no specific grant from any funding agency in the public, commercial, or not-for-profit sectors.

\section{CONFLICT OF INTEREST}

The author have declared that no competing interests exist.

\section{ACKNOWLEDGMENT}

We thank the Provincial Agriculture, Fisheries and Food Division in South Kivu for their support for its collaboration, the various structures of Environmental civil society in South Kivu and students from the different University institutions who participated in the data collection. We would like to thank FAO Bukavu office, which involved us in their children's restoration project in South Kivu.

\section{REFERENCES}

[1] Anzoumanan K., B K.Yao, M. K.Amani, K. B. Dje, et S. Diallo, " Impact des Évolutions Climatiques sur les Ressources en eau des Petits Bassins en Afrique Sub-Saharienne: Application au Bassin Versant du Bandama à Tortiya (Nord Côte d'Ivoire)“. Eur. Sci. Jour., vol 15, no 9, pp. 84-105, 2019 URL: http://dx.doi.org/10.19044/esj.2019.v15n9p84

[2] Bahin Y-B., S. Haida, et J-L. Probst" Analyse de la variabilité hydroclimatique et impacts des barrages sur le régime hydrologique d'une rivière de zone semi-aride". Eur. Sci. Jour., vol.3. no 5, pp. 509-525, 2017. http://dx.doi.org/10.19044/esj.2017.v13n5p509

[3] Adger N.W., N.W. Arnell, and E.L., Tompkins, “Successful Adaptation to Climate Change”. Gl. Envir. Ch., vol 15, no 2, pp. 77-86, 2005 http://dx.doi.org/10.1016/j.gloenvcha.2004.12.005

[4] Yegbemey R., K. O. Humayun Awoye, J. Yabi, and A. Paraïso, Managing the agricultural calendar as coping mechanism to climate variability: A case study of maize farming in northern Benin, West Africa, Vol. 3, J0 - Climate Risk Management, 2014

[5] Perry J. et Falzon C., L'adaptation au changement climatique pour les sites du patrimoine mondial naturel Guide pratique, P 90, 2014.

[6] Gautier K. O. J., O. Y. Marie-Solange, Y. K.Theodore, Y. A. Fabrice, B.Derving, L.Theophile, and H. Jean. "Impact of Climate Variabilty on Water Resources and Population Health in the South Eastern Coastal Area of Côte d'Ivoire". Eur. Sci. Jour., vol 12, no 35, pp. 12-31, 2016 https://doi.org/10.19044/esj.2016.v12n35p319

[7] PND-RDC, Pauvreté et conditions de vie des ménages au Sud-Kivu: Unité de lutte contre la pauvreté, P 18, 2015 
Aruna Sefu, Kimenya Musailwa, Bitundu Mwanya Tanya, M’opandu Mondonge, Lwimo Mukenge, Kambale Kavusa Gentil, and Mangambu Mokoso Jean De Dieu

http://www.undp.org/content/dam/undp/documents/partners/civil_society/publications/policies_and_s trategic_documents/Strategie_du_PNUD_pour_le_renforcement_de_la_societe_civile_et_de_l\%27engagemen t_civique_FINAL.pdf

[8] Wood A., A. Dixon, and M. McCartney, Wetland Management and Sustainable Livelihoods in Africa, 1 edition, Routledge/England, P. 304, 2013. ISBN: 9781849714129

[9] Bognini S. Impacts des changements climatiques sur les cultures maraîchères au nord du Burkina Faso: cas de Ouahigouya, P 38, 2017

[10] Tchatchou L. C., K. Sufo, P.T. Saray, A.M. Tiani, D.J. Sonwa, F. Kengoum, B. Locatelli, M. Y. Bele, , A. Munoh, et C. Kenfack, Changement climatique dans le Bassin du Congo : Informations et connaissances échangées entre les acteurs. Center for International Forestry Research (CIFOR)., 2017, ISBN 978-602-1504-93-2, https://doi.org/10.17528/cifor/005622

[11] White F., "The AETFAT chorological classification of Africa: history, methods andapplications". Bul. Jar. Bot. Nat. Bel., vol 62: pp. 225-281, 1993.

[12] Messerli B. and J.D. Ives, Mountains of the world: a global priority. Parthenon Publishing Group, New York, Etats-Unis and Carnforth, Royaume-Uni, P 495, 1997.

[13] USAID DRC 2018: Food for Peace Climate Risk Profile, P 26, 2018. www.climatelinks.org

[14] Ndeko B., B. Chuma, A. Muguma, N. Shakanye , C.Bukomarhe et Z.Kulimushi, "Diagnostic des systèmes de production à base du sorgho dans les hautes et basses altitudes au Sud - Kivu à l'Est de la RDC: perspectives d'amélioration de la filière". Afr. SCIE. vol 15, no 1: pp, 37 - 49, 2019.

[15] CISHESA T-R. "Production de la tomate, contraintes et opportunités en territoire de Walungu, Sud-Kivu à l'Est de la RD Congo" Inter. Jour. Innov. Scie. Res., Vol 23, no 1, pp. 15-27, 2016 http://www.ijisr.issrjournals.org/

[16] Ndjadi S. S., G. C. Basimine, G. F. Masudi, A.M. Kyalondawa, Y. Mugumaarhahama, S.N et Vwima “Déterminants de ma performance des exploitations agricoles à Kabare, Sud-Kivu Est de la République Démocratique du Congo". Agron. Afr., vol 31, no2: 199 - 212, 2019

[17] N"DJAFA O.H., Vulnérabilité, impacts et stratégies d'adaptation, de la population locale à la variabilité et aux changements climatiques, rapport centre régional Agrhymet, P 28, 2009.

[18] ARUNA J. Evaluation économique des services écosystémiques du Parc National de Kahuzi-Biega : cas des eaux douces dans le secteur de la haute altitude des Chefferies de Kabare \& Buhavu au Sud-Kivu. Mémoire de maitrise en science de l'environnement, UNIVERSITE EVANGELIQUE EN AFRIQUE/BUKAVU, RDC., P 103, 2019.

[19] Kabonyi N.C.: "Etude palynologique de la séquence sédimentaire de Musisi-Karashoma II, Sud Kivu (R.D.Congo) : Synthèse de l'évolution environnementale du Sud Kivu au cours des deux derniers millénaires". $\begin{array}{llllll}\text { Geo-Eco-Trop, } & \text { vol } & 31, & \text { no } & 2: & \text { pp. }\end{array}$ http://www.geoecotrop.be/uploads/publications/pub_311_795318.pdf

[20] Matabaro S.K., T. M. Bibentyo, W. M. Sahani, C. Michellier et O. Dewitte: "Glissements de terrain et éléments à risque dans le bassin versant de la Wesha (Bukavu, RD Congo) ". Geo-Eco-Trop, vol. 41, no 2: pp.233-248, 2017.http://www.geoecotrop.be/uploads/publications/pub_412_06.pdf

[21] Corominas J., C. Van Westen, P. Frattini, L. Cascini, J.P. Malet, S. Fotopoulou, F. Catani, M. van Den Eeckhaut, O. Mavrouli, F. Agliardi, K. Pitilakis, M.G. Winter, M. Pasteur, S. Ferlisi, V. Tofani, J. Hervas and J.T. Smith, "Recommendations for the quantitative analysis of landslide risk." Bul. Eng.Geo. Envir., vol. 79: pp. 209-263, 2013.

[22] ARUNA S-J, 2011 : La consommation du combustible braise (charbon de bois) par les ménages de Bukavu et son impact sur la déforestation au Sud-Kivu, mémoire de licence, ISDR-Bukavu, 28 p, 2011.

[23] GIEC (GROUPE D'EXPERTS INTERGOUVERNEMENTAL SUR L'EVOLUTION DU CLIMAT):: Bilan sur les changements climatiques: Rapport de synthèse GIEC, Stockholm, en Suède, 34 p, 2013.

[24] SOCEARUCO \& CBCS 2019: Rapport de la journée mondiale des zones humides, https://www.worldwetlandsday.org/c/document_library/get_file?uuid=b0468755-df7d-8d7e-def7ecabff87eee3\&groupId=10197

[25] Mangambu M.; K. Mushagalusa, et N. Kadima, "Contribution à l'étude phytochimique de quelques plantes médicinales antidiabétiques de la ville de Bukavu et ses environs (Sud-Kivu, R.D.Congo)". Jour. Appl. Biosci., vol. 75: pp. 6211- 6220, 2014. https://doi.org/10.4314/jab.v75i1.7 
Climate Risks Assessment, Opportunities Related to The Evolution of Ecosystems and Limitation of The Provision of Ecosystem Services: Landscape Case of South-Kivu (Albertine Riflt, Drc)

[26] Vircoulon T., “Politique Étrangère”. Inst. Fra. Rel. Inter., 75 (3): pp.694-696, 2010. www.jstor.org/stable/42715809

[27] Mangambu M. 2016: Diversité, Biogéographie et Ecologie des Ptéridophytes: Cas de massif montagneux du Parc National de Kahuzi-Biega à l’Est de la RD. Congo. Editions universitaires européennes, P 354, 2016. ISBN: 9783639507126

[28] PUND RDC 2009: Environnement et Energie en République Démocratique du Congo. httpt://w.w.w.cd.undp.org.projects.

[29] Laburthe-Tolra P., Critique de la raison ethnologique, Paris, PUF, coll. »Ethnologies-contreverses », 1998. Lalive d'Epinay, «Récit de vie, ethos et comportement : pour une exégèse sociologique », in Remy, J., Ruquoy., Presses Universitaires de France., P 128, 1998.

[30] Atlan. J et Paquette, D., "Le Processus d'identification du défi d'adaptation (PIDA) dans l'évaluation psychoéducative". Rev. Psychoéd., vol 41, no 2: pp.259-270, 2012. https://www.unipsed.net/ressource/pida/

[31] Hénaff M et S. Lavi-Strauss, Philosophie de la méthodologie des recherches. Ed. : Pierre Belfond (Coll. « Les Dossiers Belfobd »), P126, 1991.

[32] Estes JA., Tinker MT., et TM. Williams: "Killer whale predation on sea otters linking oceanic and nearshore ecosystems" Science vol. 282, no 5388, pp.473-476 https://doi.org/10.1126/science.282.5388.473

[33] Hammer, O., , D. Harper, and P. Ryan: PAST: Paleontological Statistics software package for education and data analysis. Paleont. Electr. Vol.4, no 1: 1-9, 2001 http://palaeoelectronica.org/2001_1/past/issue1_01.htm.

[34] Mazerollo, P. Statistique descriptive: Moyenne arithmétique. Laboratoire de gestion des écosystèmes (GECOS), Lausanne, P 121, 2012.

[35] Nkulu M. F. , et A. P. Ngulungu: Sécurité alimentaire et système d'alerte précoce en RDC, stratégies pour une meilleures prévention des crises alimentaires, Publications de la Konrad Adenauer Stiftung Kinshasa, MÉDIASPAUL - Kinshasa, P 96, 2018. www.mediaspaul.cd

[36] Ganza D, N.Cirezi, A.Huart, P.Baraka, J.Biral, M. Kazamwali, I.Diansambu, L. Mubalama, J. Sève, et B. Michel, ” Influence des caractéristiques des exploitants sur l'adoption des variétés améliorées de manioc à Kabare, province du Sud-Kivu dans l'Est de la RD Congo". Inter. Jour. Innov. Appl. Stud., vol 27, no 1 : 43-53, 2019. http://www.ijias.issr-journals.org/abstract.php?article=IJIAS-19-008-10

[37] Mushakulwa W., "Facteurs d'adoption des variétés améliorées de manioc dans le groupement de Kalungwe". Cah. Ceruki, Nouv. Sér., VoL.51, no 1, pp 1-10, 2016.

[38] Ameua M., J. Hirea, D. Kamalanduac, G.Khisad, C. Koko Nzezab, C.N. Ndambi , et W. A. Oduori Champs-écoles paysans sur le manioc: Ressources à l'intention des facilitateurs d'Afrique sub-saharienne, FA0, Rome, P 233, 2014 : http://www.fao.org/3/a-i3447f.pdf

[39] FAO. Une production céréalière record et des échanges quasi record en 2019-2020, Rome, P 572020.

[40] HARVEST PLUS, Driving Impact: HarvestPlus Annual Report 2016 https://www.voaafrique.com/a/lamalnutrition-un-mal-qui-touche-pres-de-huit-millions-de-personnes-en-rdc/3642066.html accedé le 06.01 .2020

[41] M’Mpango B., M. Imani, M.Nyakabwa \& Z.Balezi : 'Diversité végétale du sous-bois et stocks de carbone dans les arboretums en zone de montagne dans la province du Sud-Kivu, R D. Congo”. An. Scie. Scie. Appl., Vol. 4(3/4), pp. 84-106, 2018.

[42] Mabah L., Temple L. et Havard M., Les déterminants de l'adoption d'innovations techniques sur maïs au Cameroun, une contribution à la sécurisation alimentaire, AGRAR-2013: 1ère conférence de la recherche africaine sur l'agriculture, l'alimentation et la nutrition. Yamoussoukro, Côte d'Ivoire, 4-6 juin 2013, Les presses agronomiques de Gembloux, pp. 283 - 2917, 2015

[43] UICN- PACO, Rapport Annuel. ed. Ouagadougou/Burkina-Faso, Presse de Union Internationale pour la Conservation de la Nature et de ses Resource, 2016. www.Iucn.prg/paco

[44] Foe B., : Changement climatiques, accès à l'eau potable et santé publique : entre réalités et perspectives en Afrique, 16p. Institut de Recherches Socio Anthropologiques (IRSA/UCAC), Cameroun École Doctorale Pluridisciplinaire (EDP/UAC), Bénin, 202, 2017 
Aruna Sefu, Kimenya Musailwa, Bitundu Mwanya Tanya, M’opandu Mondonge, Lwimo Mukenge, Kambale Kavusa Gentil, and Mangambu Mokoso Jean De Dieu

[45] Aruna, J. La Consommation de Braise à Bukavu et la Déforestation en RD CONGO Les causes de la déforestation en RDC; Cas de la Province du Sud-Kivu. Edition universitaire européenne, P 116, 2015. ISBN :3841749666, 9783841749666

[46] FAO. Nutitious seeds for a sustainable future, 2016a. www.fao.org/pulses-2016/

[47] FAO Evaluation des ressources forestières mondiales-Résultats principaux, $\mathrm{P}$ 42, 2016b. http://www.fao.org/forest-resources-assessment/fr/

[48] Akonkwa B., M. Ahouansou, M.Nshombo, et P. Lalèyè , "Caractérisation et suivi de la pêche au lac Kivu pour une gestion durable de ses ressources halieutiques". Eur. Scie. Jour., vol 3, no 21 : pp. 269-292, 2017, http://dx.doi.org/10.19044/esj.2017.v13n21p269

[49] Masilya P. "L'avenir de la pêche au lac Kivu (R.D. Congo) : Que faire de Lamprichthys vtanganicanus, un poisson récemment introduit au lac Kivu ?" Rev. Quest. Scient., vol.182, no4: pp.425-432, 2011.

[50] Kibwana D.K, A.M. Makumyaviri, et J.L.Hornick, "Pratiques d'élevage extensif et performances de bovins de race locale, et croisée avec des races laitières exotiques en République démocratique du Congo". Rev. Elev. Méd. Vét. Pays Trop. , vol.65, no3-4 : pp. 67-74, 2012.

[51] PNUD (2014). Nord Kivu et Sud-Kivu: Mettre les vaches au service des femmes agricultrices.https://www.cd.undp.org/content/rdc/fr/home/ourwork/povertyreduction/successstories/ traction-animale.html

[52] Akilimali J., DS.Wasso , P.Baenyi , JB. Bajope, "Caractérisation des systèmes de production porcine de petits exploitants dans trois zones agro-écologiques du Sud-Kivu en République Démocratique du Congo". Jour. Appl.Bioscie., vol. 120: 12086-12097, 2017 https://dx.doi.org/10.4314/jab.v120i1.11

[53] Moula, N., N. Antoine-Moussiaux, F.Farnir, , J. Detilleux, et P. Leroy " Réhabilitation socioéconomique d'une poule locale en voie d'extinction : la poule Kabyle (Thayazit lekvayel)". Ann. Méd. Vét., vol. 153, pp178186, 2009. http://www.facmv.ulg.ac.be/amv/articles/2009_153_3_05.pdf

[54] Bisimwa N. P, B. Ayagirwe, R.Lugamba, S.Wasso, B. C Aksanti , et B E, Bisimwa, " Le système de production de la poule locale contraigne son développement au Sud-Kivu, Est de la République Démocratique du Congo". Jour. Appl. Bioscie. Vol. 135: pp. 13821 - 13830, 2019. https://dx.doi.org/10.4314/jab.v135i1.8.

[55] Moula, N. Biodiversité avicole dans les pays industrialisés et en développement caractérisation et étude des performances de production de races gallines locales. Thèse, Académie universitaire WallonieEurope, Université de Liège; P.261, 2012.

[56] Salehi, E., and L. Zebardast, " Application of Driving force- Pressure- State- Impact- Response (DPSIR) framework for integrated environmental assessment of the climate change in city of Tehran" Poll., vol. 2, no 1: pp 83-92, 2016 https://dx.doi.org/10.7508/pj.2016.01.009

[57] GIZ, EURAC \& UNU-EHS, Climate Risk Assessment for Ecosystem-based Adaptation - A guidebook for planners and practitioners, P, 115, 2018. Bonn: GIZ. https://www.adaptationcommunity.net/wpcontent/uploads/2018/06/giz-eurac-unu-2018-enguidebook-climate-risk-asessment-eba.pdf

[58] Ali R-R, Saima B., et M Verdone, L'adaptation Fondée sur les, Ecosystèmes: Arguments Economiques pour Promouvoir les Solutions Fondées sur la Nature en réponse au Changement Climatique, UICN, 2015

[59] GIZ, Emerging lessons for mainstreaming Ecosystem-based Adaptation: Strategic entry points and processes Lili Ilieva and Thora Amend. Deutsche Gesellschaft für Internationale Zusammenarbeit (GIZ) GmbH, Bonn, P 35, 2019a www.adaptationcommunity.net

[60] GIZ, Governance for Ecosystem-based Adaptation Understanding the diversity of actors \& quality of arrangements, P 64, 2019b:.

[61] Fatiavana R, H. Tanindrazana, et H.,Fandrosoana : Stratégie nationale sur la restauration des paysages forestiers et des infrastructures vertes au Madagascar, ministère de l'environnement, P 121, 2017

[62] MEA (MILLENIUM ECOSYSTEM ASSESSMENT), 2003: Les écosystèmes et le bien-être de l'Homme : Un cadre d'évaluation. Résumé., 2003. http://www.unep.org/maweb/en/index.aspx 